\title{
POLÍTICAS PÚBLICAS E INTERESSES PRIVADOS: uma análise a partir do Corredor de Nacala em Moçambique ${ }^{1}$
}

\author{
Ana Garcia* \\ Karina Kato**
}

\begin{abstract}
A política externa brasileira, a partir de 2003, apresentou uma notória curva em direção ao aprofundamento e à expansão das relações com outros países e regiões “do Sul global”. Nesse contexto, o continente africano ganhou importância para as relações internacionais do Brasil. O objetivo do artigo é avançar na compreensão da participação do setor empresarial na cooperação brasileira em Moçambique. Os resultados demonstram que as empresas e seus projetos privados se mesclam nos territórios. Examinaremos o caso do corredor logístico de Nacala, interseção das principais e maiores iniciativas de cooperação e de investimento de empresas brasileiras em Moçambique. O cenário construído nos mostra um tabuleiro no qual a cooperação Sul-Sul e, dentro dela, a cooperação brasileira, não podem ser compreendidas sem serem considerados sua relação com os interesses e investimentos empresariais, o jogo de poder com outros países e as políticas de instituições multilaterais como o Banco Mundial.
\end{abstract}

PALAVRAS-CHAVE: Multinacionais brasileiras. Infraestrutura. Cooperação Sul-Sul. Moçambique. Desenvolvimento

\section{INTRODUÇÃO}

A política externa brasileira apresentou uma notória curva em direção ao aprofundamento e à expansão das relações com o "Sul global" a partir de 2003, com o governo Lula. Vigevani e Cepaluni (2006) a caracterizaram como a busca de "autonomia pela diversificação", na qual a autonomia resulta da abertura de relações políticas e comerciais com mais parceiros, como as economias emergentes dos BRICS, países da América do Sul e novos parceiros da África e do Oriente Médio. As cha-

* Universidade Federal Rural do Rio de Janeiro. Instituto de Ciências Humanas e Sociais.

Rodovia BR-465, Km 7. Jardins. Cep: 23890001. Seropédica - Rio de Janeiro - Brasil. anasaggioro@gmail.com

** Universidade Federal Rural do Rio de Janeiro. Instituto de Ciências Humanas e Sociais - ICHS. Departamento de Desenvolvimento, Agricultura e Sociedade.

Avenida Presidente Vargas - 417. Centro. Cep: 20071003. Rio de Janeiro - Rio de Janeiro - Brasil. anirakato@yahoo.com

${ }^{1}$ A pesquisa que embasou este artigo é parte do projeto "Direitos Humanos e Indústria Extrativa", da Justiça Global juntamente com o PACS e a Rede Justiça nos Trilhos, e parte do projeto "A Cooperação Brasileira para o Desenvolvimento Internacional com Angola e Moçambique: entre o discurso solidário e prática pragmática” (chamada MCTI/ CNPq/MEC/CAPES n. 43/2013) da Universidade Federal da Bahia. Agradecemos a Miguel Borba de Sá (PACS/PUC -Rio), Elsa Sousa Kraychete (UFBA), bem como aos participantes do GT Teoria e Prática das Relações Internacionais da ANPOCS por suas valiosas críticas, comentários e sugestões nas versões preliminares desse artigo madas "relações Sul-Sul" formaram as bases para a busca de uma maior participação e uma incidência nas instituições globais e fóruns multilaterais. Junto a isso, consolidou-se o que Cervo (2009) chamou de internacionalização da economia brasileira, quando o país ascendeu à posição de global player e se observou a expansão internacional das empresas brasileiras, apoiadas em políticas públicas como o crédito subsidiado. O estreitamento das relações Sul-Sul atribuiu a esses grandes grupos econômicos um grande respaldo político na sua atuação regional e global.

Foi nesse contexto que a África ganhou importância nas relações internacionais do Brasil. Entre 2002 e 2012, o comércio entre o Brasil e o continente africano aumentou seis vezes, passando de US\$ 4,9 para US\$ 26,5 bilhões (BNDES, 2013). Empresas brasileiras do setor extrativo e de construção civil, que chegaram ao continente ainda na década de 1970, avançaram com novos projetos nos últimos anos. Esse avanço das multinacionais brasileiras se fez acompanhar do crescimento da chamada "cooperação para o desenvolvimento" nas áreas da agricultura, educação e saúde. Apontamos, 
em trabalhos anteriores (Garcia; Kato e Fontes, 2013), para a necessidade de adoção de uma perspectiva interrelacionada sobre o tripé "investimento, cooperação e financiamento”.

É relevante aclarar que a cooperação para o desenvolvimento e o investimento externo brasileiro partem de lógicas distintas nos discursos oficiais. A cooperação é apresentada como forma de "diplomacia solidária", desvinculada de interesses comerciais, pautada na "horizontalidade" das relações e operada apenas quando demandada pelo governo receptor (IPEA e ABC, 2010; MRE, 2010). O discurso oficial enfatiza as lições aprendidas no plano doméstico em temas como inclusão social, desenvolvimento agrícola e sustentabilidade (IPEA e Banco Mundial, 2011; Giugale, 2012). O ex-ministro Celso Amorim sintetizou essa ideia, ao afirmar que "para todo problema africano, existe uma solução brasileira” (Amorim, 2011).

Os investimentos, por sua vez, seguem a lógica empresarial que busca a expansão dos negócios, a redução de custos e o aumento de lucros. A viabilidade econômica dos projetos e a garantia de lucros não passam pela noção de "solidariedade" ou "horizontalidade". Projetos de responsabilidade empresarial, nessa perspectiva, são mais bem compreendidos como ações de legitimação da atuação empresarial nos territórios ๑ี e (ou) de criação de vantagens competitivas.

Ao chegarem aos países receptores e aos \& territórios concretos de realização, a coopera-

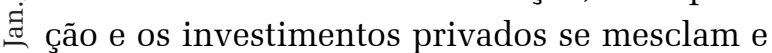

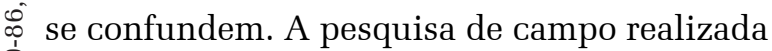

$0^{\circ}{ }^{2}$ As autoras realizaram pesquisa de campo em Moçambi¿ que no período de 16 a 30 de agosto de 2014. Nesse perío- do, foram realizadas 15 entrevistas com camponeses, ato-

จ res governamentais, lideranças tradicionais, representan-

$>$ tes de movimentos sociais, trabalhadores da linha férrea,

î funcionários do porto, gestores públicos, pesquisadores e

- acadêmicos, entre outros. A pesquisa de campo o Corredor

$\stackrel{\pi}{\perp}$ de Nacala (norte de Moçambique) inclui paradas para rea-

శ్ lização de entrevistas em: Tete - Moatize (reassentamento

- 25 de setembro e Cambulatsitsi); às margens do lago Nias-

IJ sa no Malauí (estação de Balaka e N'Kaia); Mandimba (Mo-

ç çambique); Cuamba (onde visitamos um apeadeiro duran-

te a partida do trem); Mutuali; Ribáuè; Nampula (visita e

entrevista com o reitor da Universidade do Lúrio, entre-

vista com Combonianos); Nacala (entrevista com Justiça e

Paz, entrevistas e visita ao Porto de Nacala, a Nacala-a-Ve- presas e seus projetos privados que aparecem nos territórios. O caso do corredor logístico do norte de Moçambique (Nacala) é elucidativo desse processo, revelando, de um lado, o protagonismo das empresas e, de outro, a complementaridade das políticas de cooperação com os investimentos. Focaremos na infraestrutura e na logística no corredor de Nacala como eixo de conexão entre investimento e cooperação.

Para compreender a importância do investimento em infraestrutura nas áreas periféricas para o processo de acumulação do capital, a concepção teórica que permeia o artigo está baseada em leituras críticas e marxistas, como Harvey (2005; 2007). O autor baseia-se em Rosa Luxemburgo, que sustentava a ideia da importância das áreas externas ao capitalismo ("pré-capitalistas") para o aprofundamento da acumulação capitalista. Para Harvey, a sobreacumulação em um dado sistema territorial gera excedente de capital, que precisa ser deslocado numa nova ordenação espaçotemporal. Assim, investimentos externos diretos financiados por crédito são deslocamentos espaçotemporais que respondem, de forma ampla e sempre temporariamente, ao problema de absorção do capital excedente. A temporalidade (por exemplo, o financiamento estatal através de um sistema de crédito) envolve investimento de capital de longo prazo (por exemplo, infraestrutura) com deslocamento espacial, o que implica uma expansão geográfica, com a abertura de novos mercados, exportação de capital e de commodities. Para os países centrais e semiperiféricos (como o Brasil), a criação de novos e dinâmicos centros de acumulação nesses territórios traz benefícios na medida em que cria a necessidade de realização permanente de novos investimentos (e, portanto, de transferência de novos excedentes). Tais investimentos também geram novas demandas por bens e construção de capital fixo (como ferrovias, represas e outras obras de infraestru-

lha, ao aeroporto construído pela Odebrecht, e entrevista com o GAZEDA); e Maputo, entrevista com o Ministério das Finanças, com a UNAC, ADECRU e acadêmicos. 
tura). Isso coloca em marcha diferentes formas de acumulação mediante desapossamento, resultando em um desenvolvimento desigual ao longo da história geográfica do capitalismo.

A partir dessa perspectiva teórica, procuramos avançar no entendimento da relação que se estabelece entre o setor empresarial e a cooperação brasileira em Moçambique, o que revela a complexa relação estabelecida entre Estado, políticas públicas e empresas na atuação internacional do Brasil. Procuramos chamar a atenção, no marco do crescimento do Brasil como potência emergente, como as componentes do tripé "investimento, cooperação e financiamento" operam articuladas com o objetivo de garantir a ampliação da acumulação capitalista. Adicionalmente, apontamos para a centralidade que a infraestrutura ganha nas estratégias das instituições financeiras internacionais e na dinâmica de apropriação de recursos naturais.

\section{O APOIO ESTATAL À INTERNACIO- NALIZAÇÃO DE EMPRESAS BRASI- LEIRAS}

A ascensão das multinacionais brasileiras se fez acompanhada do aumento do fluxo de investimentos Sul-Sul. Esse movimento começou a chamar a atenção em meados dos anos 2000, quando o World Investment Report da UNCTAD destacou, pela primeira vez, que o volume de investimento externo direto (IED), originado de economias "em desenvolvimento”, acumulara US\$ 133 bilhões em 2006 (17\% do fluxo mundial). O mais recente relatório mostrou que, em 2014, 39\% das saídas globais de IED eram de economias em desenvolvimento e em transição (UNCTAD, 2014). A internacionalização de firmas brasileiras passou por distintas fases, tendo se iniciado no final da década de 1960, com a Petrobras e as empresas de construção civil, impulsionadas, em parte, pelos governos da ditadura empresarial-militar (Campos, 2014). Passou por uma contração na década de 1980 (a "década perdida" da economia brasileira, com a crise da dívida) e foi retomada nos anos 1990 com os processos de privatização e abertura da economia brasileira. Foi, entretanto, a partir de 2003, com o governo de Luís Inácio Lula da Silva, que esse processo se acentuou. Se, até 2003, os investimentos brasileiros no exterior eram de aproximadamente U\$ 1 bilhão por ano, eles saltaram, entre 2004 e 2007, para U\$ 14 bilhões por ano, em média (Valor Econômico, 2009). Evidenciando essa tendência, o Banco Central do Brasil informou que os ativos totais de capital brasileiro no exterior somaram US\$ 391,6 bilhões em 2013, destacando-se os investimentos brasileiros diretos no exterior (IBD), que atingiram US\$295,4 bilhões (BCB, 2013). Em 2001, esse volume era de somente US\$ 49,7 bilhões.

No que concerne ao escopo geográfico, América Latina, África e Oriente Médio passaram a figurar como novas opções para acesso a recursos e mercados para crescentes exportações e investimentos brasileiros (MRE, 2010). De acordo com a Fundação Dom Cabral, tem sido crescente o número de empresas brasileiras presentes nos países da Comunidade de Países de Língua Portuguesa (CPLP). Portugal é o país com maior presença de empresas brasileiras, seguido por Angola e Moçambique. São citados como fatores positivos o idioma comum e a similaridade institucional, a maior facilidade no relacionamento com fornecedores, clientes e parceiros comerciais e a proximidade cultural (FDC, 2014).

O debate sobre políticas públicas de apoio à internacionalização de empresas no Brasil contrapõe a visão de que o investimento "desviado" para o exterior leva à redução da geração de empregos e da arrecadação fiscal àquela que entende que a internacionalização seria " $a$ única alternativa" para firmas na era globalizada (Iglesias e Motta Veiga, 2002, p. 430).

Nos últimos anos, o governo brasileiro implementou uma série de políticas públicas e institucionais de apoio (direto ou indireto) às multinacionais brasileiras. Dentre as 
mais importantes, estão: tratados comerciais de investimento e sobre bitributação; abertura de novas embaixadas em países africanos; aumento significativo da "cooperação internacional para o desenvolvimento"; financiamento direto com créditos à exportação de produtos e serviços no exterior; e a organização de visitas de comitivas e de feiras de negócios com o envolvimento direto do setor empresarial brasileiro com apoio do MIDIC e da APEX. Elas se fazem acompanhadas de um contínuo processo de internacionalização de instâncias da burocracia brasileira, como os escritórios da Embrapa (Gana), da APEX (Angola), da Fiocruz (Moçambique) e do IPEA (na Venezuela). ${ }^{3}$ A esse movimento acrescentamos também a internacionalização do BNDES (Londres, Montevidéu e Johanesburgo).

Atualmente, na África, o Brasil possui tratado internacional para evitar a bitributação somente com a África do Sul (Receita Federal Brasileira, s/d). Os tratados comerciais e de proteção de investimento, contudo, têm se tornado um novo instrumento da política externa brasileira. O Brasil assinou, recentemente, tratados de facilitação da cooperação e do investimento com dois países africanos: Moçambique e Angola (MRE, 2015). Eles se diferenciam dos demais tratados por garantir que todo o contencioso envolvendo empresas brasileiras, em • território moçambicano e angolano, será negoస. ciado entre os governos, transferindo para o Estado brasileiro a responsabilidade de nego-

brasileiras. Ele também inclui um anexo sobre a brasileiras. Ele também inclui um anexo sobre a responsabilidade social corporativa, entendida iิ como um diferencial positivo dos investimen$\rightarrow$

કิ ${ }^{3}$ Segundo Milani e Pinheiro (2014), os processos de formulação, decisão e implementação da política externa

brasileira são resultantes de "coalizões, barganhas, dispu-

tas, acordos entre representantes de interesses diversos",

passando, além do Itamaraty, também por outras pastas

I e órgãos do governo (saúde, educação, cultura, meio am-

biente, agricultura etc.), e mesmo por unidades subnacio-

nais. Assim, a distinção rígida entre "high" e "low politics"

gradualmente se dilui, na medida em que a política ex-

terna assume questões culturais, de educação e a própria

cooperação técnica como eixos centrais. tos brasileiros frente a outros, embora suas cláusulas sejam voluntárias e não vinculantes. O novo acordo intergovernamental, em nossa perspectiva, favorece os interesses brasileiros em Moçambique e deve ser lido como uma reação dos atores brasileiros (governamentais e não governamentais) frente aos recentes conflitos que têm surgido entre empreendimentos de mineração da Vale e o programa de cooperação no agronegócio, o ProSavana, nesse país.

O Ministério de Desenvolvimento, Indústria e Comércio (MDIC) atua mediante a organização de missões empresariais e feiras comerciais, além de escritórios internacionais da Agência Brasileira de Promoção da Exportação (APEX). Foram abertas representações da APEX em oito países, com a missão de identificar oportunidades de negócios para expandir o comércio e o investimento brasileiros nas diferentes regiões. Na África, a APEX está situada em Angola. A abertura de novas embaixadas também foi significativa durante o governo Lula, sendo 18 localizadas na África, totalizando 34 embaixadas nesse continente (Sennes e Mendes, 2009; MRE, 2010).

Para compor esse quadro, foi também durante o governo do presidente Luis Inácio Lula da Silva que o Brasil passou a ser, além de um receptor, também um doador de ajuda internacional, aportando US\$ 33 milhões em 2010 frente a US\$ 1,5 milhão em 2003 (MRE, 2010). A cooperação técnica brasileira é caracterizada por um elevado grau de descentralização (Quadro I). Segundo a Agência Brasileira de Cooperação (ABC), mais de 70 instituições brasileiras estão envolvidas em projeto de cooperação. A ausência de um corpo institucional articulador e norteador das políticas de cooperação pode resultar em ações contraditórias e sobrepostas (Renzio et. al., 2013). Além da ABC, novos atores, como a Empresa Brasileira de Pesquisa Agropecuária (Embrapa) e a Fundação Oswaldo Cruz, vêm se tornando entidades bastante ativas na promoção da cooperação e da ajuda ao desenvolvimento. Os principais campos nos quais se dá a cooperação brasileira Sul-Sul são 
Quadro 1 - Principais ações de cooperação em agricultura do Brasil em Moçambique (2012)

\begin{tabular}{|c|c|c|c|c|c|}
\hline Projeto & Cooperação & Atores & $\begin{array}{l}\text { Exp. } \\
\text { brasi- } \\
\text { leira }\end{array}$ & Objetivos & Recursos \\
\hline $\begin{array}{l}\text { Missão de } \\
\text { cooperação } \\
\text { técnica em } \\
\text { agricultura } \\
\text { familiar e } \\
\text { resgate de } \\
\text { sementes } \\
\text { nativas }\end{array}$ & $\begin{array}{l}\text { Quadrilateral } \\
\text { (Brasil-Mocam- } \\
\text { bique-África do } \\
\text { Sul-Namíbia). } \\
\end{array}$ & $\begin{array}{l}\text { Brasil: Sec. da Presidência; IBASE; } \\
\text { Movimento Camponês Popular; } \\
\text { Movimento de Mulheres Camponesas. } \\
\text { Moçambique: MINAG; Ministério da } \\
\text { Planificação e Desenvolvimento (MPD); } \\
\text { União Nacional de Camponeses } \\
\text { (UNAC). } \\
\text { África do Sul: Ministério da Agricul- } \\
\text { tura Florestas e Pesca. Namíbia: } \\
\text { Ministério da } \\
\text { Agricultura, Águas e Florestas. }\end{array}$ & $\begin{array}{l}\text { Não se } \\
\text { aplica }\end{array}$ & $\begin{array}{l}\text { Contribuir com o fortalecimento } \\
\text { organizacional e econômico da } \\
\text { agricultura familiar dos } 3 \text { países a } \\
\text { partir da capacitação e troca de } \\
\text { experiências entre movimentos } \\
\text { sociais, técnicos e agricultores } \\
\text { sobre técnicas de resgate e uso de } \\
\text { sementes nativas. }\end{array}$ & US\$ 363.500 \\
\hline $\begin{array}{l}\text { Purchasefrom } \\
\text { Africans for } \\
\text { Africa (PAA) }\end{array}$ & $\begin{array}{l}\text { Trilateral } \\
\text { (Brasil-Moçam- } \\
\text { bique-FAO) }\end{array}$ & $\begin{array}{l}\text { Brasil: Ministério do Desenvolvimento } \\
\text { Social (MDS). Moçambique: Ministério } \\
\text { da Educação. Terceira parte executora: } \\
\text { FAO }\end{array}$ & $\begin{array}{l}\text { Programa } \\
\text { Aquisição } \\
\text { de Ali- } \\
\text { mentos } \\
\text { (PAA) }\end{array}$ & $\begin{array}{l}\text { Tem o objetivo de apoiar a } \\
\text { produção local em áreas rurais } \\
\text { com o objetivo de reduzir a } \\
\text { vulnerabilidade desses agricul- } \\
\text { tores. Em Moçambique está sendo } \\
\text { realizado nos distritos de Angonia, } \\
\text { CahoraBassa e Changara } \\
\text { (Província de Tete). }\end{array}$ & $\begin{array}{l}\text { US\$ } 11 \text { milhões } \\
\text { para ser implan- } \\
\text { tado em } 5 \\
\text { países (Etiópia, } \\
\text { Malaui, Moçam- } \\
\text { bique, Senegal } \\
\text { e Niger. }\end{array}$ \\
\hline $\begin{array}{l}\text { Programa } \\
\text { Mais } \\
\text { Alimentos } \\
\text { África }\end{array}$ & $\begin{array}{l}\text { Bilaterial } \\
\text { (Brasil-Moçam- } \\
\text { bique) }\end{array}$ & $\begin{array}{l}\text { Brasil: Ministério do Desenvolvimento } \\
\text { Agrário (MDA). Moçambique: MINAG. }\end{array}$ & $\begin{array}{l}\text { Programa } \\
\text { Mais } \\
\text { Alimentos }\end{array}$ & $\begin{array}{l}\text { Cooperação técnica e linha de } \\
\text { crédito do governo brasileiro para } \\
\text { financiar a aquisição de } \\
\text { equipamentos brasileiros por } \\
\text { equenos produtores. }\end{array}$ & $\begin{array}{l}\text { US\$ } 400 \text { mil + } \\
\text { Linha de crédito } \\
\text { de US\$ 97,59 } \\
\text { milhões (Portal } \\
\text { Brasil, 2012). } \\
\text { Cooperação com } \\
\text { seis países: } \\
\text { Gana, Zimbábue } \\
\text { Senegal, } \\
\text { Moçambique, } \\
\text { Quênia e Cuba. }\end{array}$ \\
\hline $\begin{array}{l}\text { Plataforma de } \\
\text { Inovação } \\
\text { Agrícola }\end{array}$ & $\begin{array}{l}\text { Trilateral } \\
\text { (Brasil-Moçam- } \\
\text { bique-EUA) }\end{array}$ & $\begin{array}{l}\text { Brasil: Embrapa; ABC. Moçambique: } \\
\text { MINAG; IAM. EUA: USAID } \\
\text { Moçambique. }\end{array}$ & $\begin{array}{l}\text { Não se } \\
\text { aplica }\end{array}$ & $\begin{array}{l}\text { Reforço da capacidade institucio- } \\
\text { nal e de investigação do IAM com } \\
\text { o objetivo de contribuir com a } \\
\text { melhoria da produção e da produ- } \\
\text { tividade do setor agrícola moçam- } \\
\text { bicano. Pretende fortalecer o siste- } \\
\text { ma nacional de pesquisa agrária } \\
\text { para tornar eficiente o planejamen- } \\
\text { to, a coordenação, o controle e a } \\
\text { avaliação. } \\
\end{array}$ & $\begin{array}{l}\text { US\$ 14.688.802 } \\
\text { sendo USAID } \\
\text { US\$ 2.500.000. } \\
\text { ABC } \\
\text { US\$ 4.208.802 } \\
\text { Embrapa } \\
\text { US\$ } 7.940 .000 \\
\text { Minag } \\
\text { US\$ 40.000 }\end{array}$ \\
\hline $\begin{array}{l}\text { Programa } \\
\text { Nacional de } \\
\text { Alimentação } \\
\text { Escolar de } \\
\text { Moçambique } \\
\text { (PRONAE) }\end{array}$ & $\begin{array}{l}\text { Trilateral } \\
\text { (Brasil-Moçam- } \\
\text { bique-organis- } \\
\text { mos interna- } \\
\text { cionais-PMA/ } \\
\text { PNUD) }\end{array}$ & $\begin{array}{l}\text { Brasil: MEC. Moçambique: Ministério da } \\
\text { Educação. Outro: Programa Mundial de } \\
\text { Alimentação. }\end{array}$ & PNAE & $\begin{array}{l}\text { Realizar a compra local de alimen- } \\
\text { tos da agricultura familiar para } 12 \\
\text { escolas-piloto selecionadas em } \\
\text { quatro províncias. }\end{array}$ & $\begin{array}{l}\text { US\$ } 1.704 .455 \\
\text { Sendo ABC } \\
\text { US\$ } 537.980 \\
\text { FNDE } \\
\text { US\$ } 61.400 \\
\text { PMA } \\
\text { US\$ } 1.037 .000 \\
\text { Mined } \\
\text { US\$ } 68.075 \\
\end{array}$ \\
\hline Pró-Alimentos & $\begin{array}{l}\text { Trilateral } \\
\text { (Brasil-Moçam- } \\
\text { bique-USAID- } \\
\text { Brasil) }\end{array}$ & $\begin{array}{l}\text { Brasil: Embrapa ; ABC. Moçambique: } \\
\text { MINAG; IAM. USAID-Brasil }\end{array}$ & $\begin{array}{l}\text { Não se } \\
\text { aplica }\end{array}$ & $\begin{array}{l}\text { Aumento da produção de vegetais } \\
\text { por meio da melhoria técnica de } \\
\text { produção e colheita na cintura } \\
\text { verde de Maputo. }\end{array}$ & $\begin{array}{l}\text { US\$ } 2.406 .724 \\
\text { Sendo Usaid } \\
\text { US\$ } 1.102 .887 \\
\text { ABC } \\
\text { US\$ } 577.295 \\
\text { Embrapa } \\
\text { US\$ } 519.200 \\
\text { Minag } \\
\text { US\$ } 207.360\end{array}$ \\
\hline
\end{tabular}

Fontes: Adaptado de Duran e Chichava (2014); Quintiere (2014); Portal Brasil (2012); Fingermann (2014).

saúde, educação, agricultura e gestão pública a financiar, a partir de 2003, o investimento (Milani \& Carvalho, 2013). Em 2012, foram des- externo de empresas brasileiras. Nesse movitinados US\$ 9.684 milhões para a cooperação mento, o próprio banco se internacionalizou, técnica com países africanos (Rossi, 2013). com a abertura da subsidiária BNDES Limited

Por fim, o Banco Nacional de Desenvol- em Londres (2009), um escritório em Montevivimento Econômico e Social (BNDES) passou déu (2009) e, mais recentemente, um escritó- 
rio em Johanesburgo (2013). O financiamento a projetos internacionais envolvendo capital brasileiro se dá pela linha direta de crédito: o BNDES FINEM. Outra forma é o BNDES Exim, que financia o exportador de produtos e serviços (linha "pré-embarque") ou comercialização no exterior ("pós-embarque"). O banco é um dos principais financiadores de infraestrutura, especialmente na região sul-americana, com grandes empreiteiras (Odebrecht, Andrade Gutierrez, Queiroz Galvão, OAS). O BNDES Exim, entre 2007 e 2015, atendeu a 542 projetos, totalizando aproximadamente US\$ 12 bilhões, para empresas de construção civil, para serviços de engenharia em construção na América Latina e na África. A concentração de recursos na construtora Odebrecht chama a atenção: 414 projetos, totalizando aproximadamente US $\$$ 7,5 bilhões (BNDES, s/d).

Além da concessão de créditos públicos a juros menores que os de mercado, o banco criou uma holding financeira para participação nos conselhos administrativos das empresas. O BNDESPar tornou-se um sofisticado instrumento estatal de acumulação de capital. Em 2012, ele detinha participação em 40 multinacionais brasileiras, conforme mostra recente pesquisa. ${ }^{4}$ A participação do BNDES em empresas também é consequência de dívidas e debêntures, que são pagas por meio de : vendas de ações, como no caso da JBS-Friboi N (Lazzarini, 2011). Na sua política para a Áfri¿ ca, além da representação em Johannesburg, สี่ o banco criou um Departamento de Suporte e

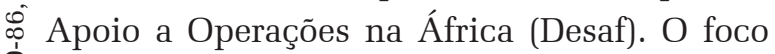
๑. é constituído de projetos de infraestrutura, e é Angola é a principal receptora, por meio da \& Odebrecht. Além do BNDES, o programa de fi今 nanciamento à exportação do Banco do Brasil, o Proex, têm aportado recursos no programa Mais Alimentos África, financiando a compra

4 O "Ranking dos Proprietários do Brasil", realizado pelo Instituto Mais Democracia e o grupo EITA, mostra a rede e త as cadeias de conglomerados, holdings, instituições finan- ceiras, pessoas físicas e famílias, além de instituições estatais, com as interligações entre eles. As informações sobre a rede que envolve o BNDESPar estão disponíveis em http:// 3 www.proprietariosdobrasil.org.br (acesso: dezembro 2012). de equipamentos agrícolas brasileiros para Gana, Senegal, Zimbábue e Moçambique (US\$ $640 \mathrm{mi}$ ) (Macedo, 2011).

As políticas públicas que apoiam a expansão internacional de empresas brasileiras, incluindo a internacionalização de instituições e agências da burocracia estatal, podem ser compreendidas no marco mais amplo da "internacionalização do Estado”. De acordo com Robert W. Cox (1987), o Estado se torna um ator econômico que joga um papel direto na acumulação de capital, com créditos e subsídios, por exemplo. Ele faz a mediação entre o mercado mundial e grupos domésticos, adequando as burocracias estatais às pressões do mercado mundial e dando mais poder e autonomia a instâncias como bancos centrais, agências de comércio exterior, agências de privatização etc. A internacionalização do Estado acompanha a internacionalização da produção.

Os documentos das instituições governamentais brasileiras revelam a ausência de uma discussão sobre impactos sociais, trabalhistas ou ambientais da atuação das empresas brasileiras. Entretanto, a ocorrência de impactos negativos sobre comunidades locais, trabalhadores e o meio ambiente revela que a atuação das empresas não tem resultado unicamente em consensos (em torno da maior competitividade e das vantagens trazidas para a economia brasileira), mas também em conflitos, dentro e fora do país. ${ }^{5}$ O caso de Moçambique, como veremos adiante, é emblemático.

\section{INVESTIMENTO, FINANCIAMENTO E COOPERAÇÃO DO BRASIL EM MOÇAMBIQUE}

De acordo com Saraiva (2012), a transição da economia socialista para uma eco-

${ }^{5}$ Para exemplos de conflitos envolvendo empresas e comunidades ou trabalhadores no Brasil, ver o Mapa de Conflitos Envolvendo Injustiça Ambiental e Saúde no Brasil, coordenado por Marcelo Firpo (ENSP/Fiocruz). Para exemplos de conflitos internacionais envolvendo multinacionais brasileiras, ver Instituto Rosa Luxemburgo Stiftung et. al. (org.) (2009), Garcia (2015), entre outros. 
nomia de mercado em Moçambique se fez acompanhada de uma postura ativa do Estado em perseguir o crescimento econômico via o incremento de investimentos estrangeiros, das exportações e das doações internacionais. Segundo Mosca e Selemane (2012), nesse período, o país deixou progressivamente de ser um exportador de bens agrícolas (açúcar, algodão, tabaco, castanha de caju), de serviços do hinterland (linhas férreas e portos) e de mão de obra (principalmente para a África do Sul), voltando-se para a consolidação do país como uma economia exportadora de recursos naturais e de commodities. Para o entendimento do contexto moçambicano, é central destacar o déficit apresentado na balança comercial, fruto da necessidade de importação de alimentos (trigo, milho, arroz e açúcar) e outros produtos básicos.

A descoberta recente de abundantes recursos naturais (reservas de carvão e outros minerais, gás, terra e clima para exploração florestal, além de commodities agrícolas e bens alimentares) reforçou essa estratégia de desenvolvimento via a atração de investimentos estrangeiros. Os primeiros investimentos estrangeiros concretizados deixaram dúvidas sobre sua contribuição para o desenvolvimento econômico e para a redução da pobreza no país (Mosca e Selemane, 2012; Duran e Chichava, 2013). Ao considerar a atual vulnerabilidade externa da economia, dependente de doações externas para fechar suas contas (com peso de 50 a $55 \%$ no orçamento do Estado), estudos atentam para o risco de que a exploração acelerada dos recursos acabe esgotando as reservas nacionais sem diversificar a economia (Mosca e Selemane, 2013). Essa lógica priorizaria megaprojetos e cadeias produtivas para exportação, em detrimento do mercado interno, da segurança e soberania alimentar e da inclusão social (Mosca, 2014).

Foi nessa conjuntura econômica e política que se deu a aproximação do Brasil com Moçambique no século XXI. Alguns autores entendem que essa relação passou de uma ignorância mútua para uma "parceria estra- tégica”, na qual o "novo” Brasil estimularia o "novo" Moçambique (Duran e Chichava, 2013). A Vale é o principal investidor brasileiro em Moçambique, tendo chegado ao país em 2004 para explorar a mina de Moatize. Atraída pela qualidade do carvão mineral de Tete e pelo boom das commodities no mercado internacional, a empresa assinou um contrato de concessão mineira para exploração da mina de Moatize, que não era explorada desde a independência em 1975 (Vale, 2013). A instalação e, posteriormente, a duplicação da mina foram realizadas em conjunto com as construtoras brasileiras Odebrecht, Camargo Correa e Andrade Gutierrez, que ganharam espaço na economia do país.

Pela natureza das atividades que realiza, a logística torna-se central nas atividades da Vale, no Brasil ou no exterior. Para o diretor executivo de Operações Integradas da Vale, no século XXI, a empresa se tornou cada vez mais uma empresa de logística, ${ }^{6}$ investindo no ciclo mina, ferrovia e porto. Em sua atuação em Moçambique, a empresa reproduziu "o modelo de sucesso adotado no Brasil”, buscando realizar a verticalização de suas operações e integrar todas as etapas produtivas, ampliando margens pela redução dos custos (Vale, 2011).

O projeto Moatize é o maior investimento da mineradora em carvão mineral (11 milhões de tonelada por ano). Suas exportações foram iniciadas pelo porto da Beira em 2011. O transporte era feito por meio da ferrovia de Sena, que conta com uma extensão de $575 \mathrm{~km}$ e tem capacidade para transporte de seis milhões de toneladas por ano (Vale, 2014). Para viabilizar a infraestrutura condicionante da sua expansão no país, a Vale adquiriu o controle da Sociedade de Desenvolvimento do Corredor do Norte (SDCN), que controlava ferrovias e portos em Moçambique e Malauí (Vale, 2011). Uma vez equacionado o problema

${ }^{6}$ A partir de 2013, devido às mudanças no mercado internacional de commodities minerais, a Vale mudou sua estratégia empresarial e passou a adotar uma política de desinvestimento (Estado de São Paulo, 2014), procurando reduzir sua participação na logística, ao mesmo tempo em que buscou aumentar suas parcerias nessa etapa. 
do escoamento, em 2012, a empresa anunciou investimentos de US\$ 6,4 bilhões na expansão da mina de Moatize, o que incluía investimentos no Corredor de Nacala, com a duplicação de uma ferrovia de $912 \mathrm{~km}$ entre a mina de Moatize e o Porto de Nacala (Terminal Privativo de Nacala-a-Velha) (O País, 2012). Em 2015, esse porto teria capacidade de exportar até 22 milhões de toneladas de carvão ao ano (Vale, 2014).

As obras no corredor de Nacala envolveram um complexo arranjo institucional, com várias concessionárias e sociedades. Os trechos que exigiam a construção de ferrovias ficaram a cargo da concessionária Corredor Logístico Integrado do Norte (CLIN) que é uma joint venture detida em $80 \%$ pela Vale e $20 \%$

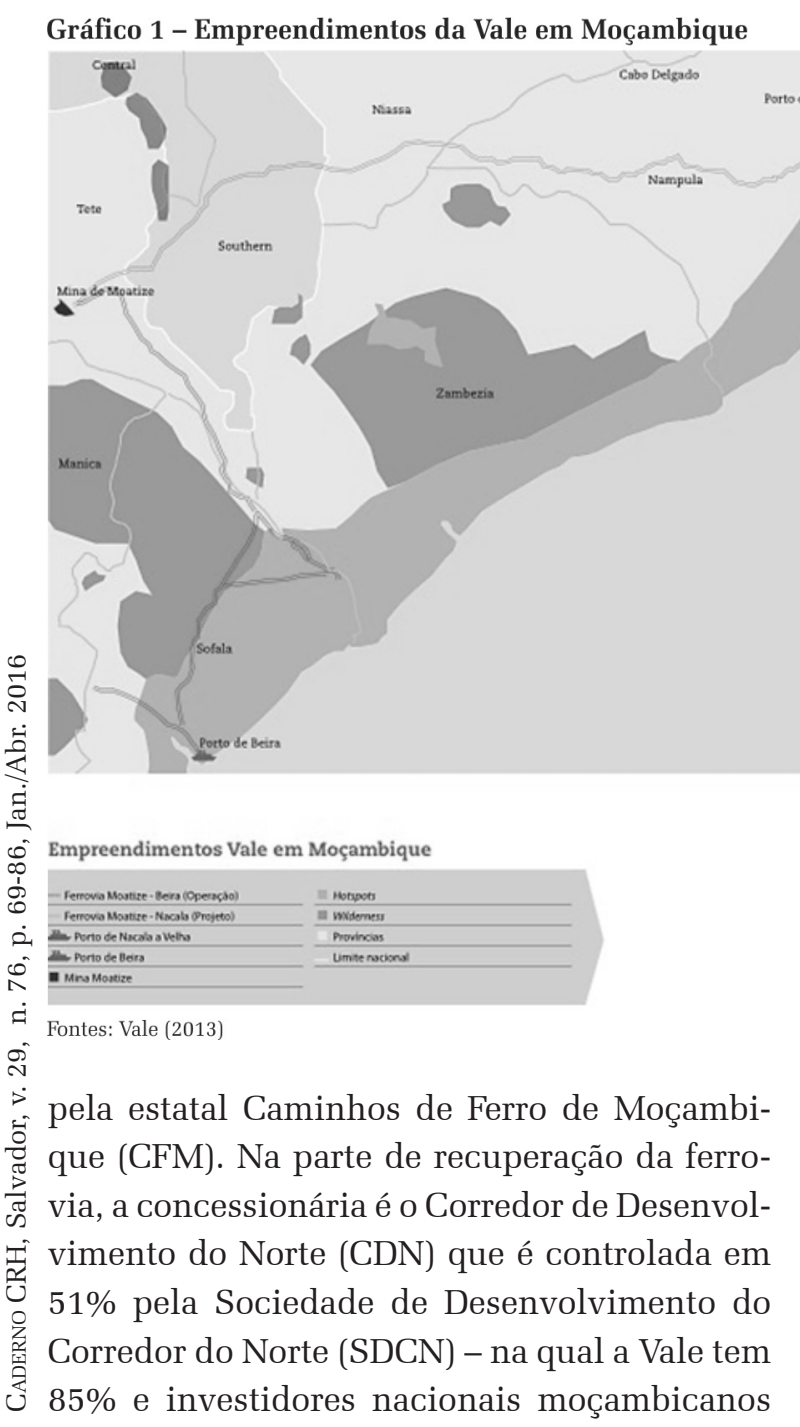

15\% - e a Caminhos de Ferro de Moçambique (49\%). Essa concessionária controla também o Porto de Nacala. No Malawi, existem duas concessionárias. Uma é a Vale Logístics Limited (VLL), que é $100 \%$ da Vale e que constrói um novo trecho de ferrovia (com a Motaengil, de Angola); a outra é a Central East African Railway Company (CEAR), que recupera uma parte da ferrovia já existente (51\% pela SDCN e $49 \%$ detidos pela $\mathrm{CFM}^{7}$ ). Em todas elas, a Vale tem um papel central e sociedade com o governo moçambicano. Essa estratégia pode ser compreendida sob a lógica de criação de vantagens competitivas pela redução dos custos via verticalização, própria do mercado de commodities (Ferreira, 2001).

Recentemente, após o boom das commodities no mercado internacional, ${ }^{8}$ a Vale mudou sua estratégia para uma política de desinvestimento em "ativos não estratégicos”, de atração de novos sócios e de foco no minério de ferro (Estado de São Paulo, 2014). Em 2014, a empresa vendeu $15 \%$ da Vale Moçambique, que possui $95 \%$ da mina de Moatize e 70\% do Corredor de Nacala, para a Mitsui. ${ }^{9}$ Após a operação, a Vale manteve $81 \%$ da mina de Moatize e $35 \%$ do Corredor de Nacala, perdendo o controle exclusivo do corredor logístico (Durão e Ciarelli, 2014).

Conflitos relacionados às atividades da Vale em Moçambique vêm sendo amplamente abordados em artigos, reportagens e em trabalhos de organizações nacionais e

\footnotetext{
${ }^{7}$ Informações obtidas em entrevista concedida por funcionária de Portos do Norte, administradora do Porto de Nacala, em Nacala.

${ }^{8}$ De 2004 a 2011 o minério de ferro sofreu alta nos seus preços, puxada pela demanda chinesa, quando começou a apresentar uma tendência de queda.

${ }^{9}$ A Vale é controlada pela Valepar (34\% do capital total). O governo federal tem 5,3\%. Os acionistas da Valepar são a Mitsui, o Bradespar, o BNDESPar e os fundos de pensão Previ, Funcef, Petros e Fundação CESP.
} 
internacionais nos últimos anos. ${ }^{10}$ Em entrevistas e pesquisa de campo anteriores (Garcia, Kato e Fontes, 2013), destacamos que os principais conflitos sociais estiveram relacionados à remoção de famílias de camponeses ${ }^{11}$ e de oleiros (fabricantes de tijolos artesanais) que ocupavam a área da mina de Moatize, e no tratamento dos trabalhadores. Segundo relatos, a empresa não foi transparente na negociação das condições de remoção das famílias. ${ }^{12}$ Tais relatos destacam que: as áreas onde os reassentamentos foram erigidos não se mostraram propícias para a agricultura, com pouco acesso à água e aos mercados próximos; as machambas (roças) e as casas das famílias foram subvalorizadas no cálculo das indenizações; as casas apresentam problemas, pois, além de não respeitarem a cultura local, com pouco tempo de uso passaram a apresentar rachaduras, devido à má qualidade da obra, problemas de infiltração e falhas de segurança. Com relação aos trabalhadores, além de problemas referentes à diferença salarial e de tratamento entre trabalhadores brasileiros e nacionais, foram relatadas a ausência de sistemas e equipamentos de segurança no ambiente de trabalho e a ocorrência de muitos acidentes. A atuação da empresa gerou muitos descontentamentos, protestos e realização de greves, bem como o crescente desentendimento com as autoridades moçambicanas.

Hoje, podemos observar algumas mudanças na forma de atuação da Vale em Moçambique. A estratégia de resposta às crescentes denúncias que lhe foram dirigidas tem se dado através do crescimento de ações de

${ }^{10}$ Alguns exemplos são: Mosca, J.; Selemane, T. Eldorado Tete: os megaprojetos de mineraç̃o. Centro de Integridade Pública (CIP), Maputo, 2011; Arrticulação Internacional dos Atingidos pela Vale. Relatório de Insustentabilidade da Vale 2012. Disponível em https://atingidospelavale. files.wordpress.com/2012/06/relatorio-insustentabilidade-vale-2012-final1.pdf; Human Rights Watch. What is a house without food? Mozambique's coal mining boom and resettlements, 2013. Disponível em http://www.hrw.org/sites/default/files/reports/mozambique0513_Upload_0.pdf

${ }^{11}$ A Vale dividiu as famílias rurais em dois reassentamentos: 25 de setembro (195 famílias) e Catemi (mais de 1000).

${ }^{12}$ Relatos obtidos por meio de entrevista com moradores de Cateme e 25 de setembro, em agosto de 2014. responsabilidade social empresarial (qualificação de mão de obra e centros de treinamentos financiados e mantidos pelas empresas brasileiras). No que concerne aos assentamentos criados pela Vale, a empresa procurou realizar outras ações, como o asfaltamento da estrada que ligava Cateme ao distrito, a implantação de programas agropecuários com doação de animais para as famílias, construção de caixas d'água etc. Ainda assim, a situação de vida dessas comunidades continua bastante precária. ${ }^{13}$

Por outro lado, observamos também uma mudança na forma de atuação do Estado moçambicano, com a criação de códigos e marcos regulatórios que procuram regularizar e monitorar as ações das empresas. Se em 2004, com a entrada da Vale, o Estado ainda não aparentava ter instrumentos legais e institucionais para lidar e monitorar esses investimentos, em 2014, o Estado moçambicano promulgou novas leis na área de mineração e petróleo que procuram garantir a participação do Estado na exploração, ampliar os tributos e melhorar as condições ambientais para esses investimentos (Santos, 2014). Para os processos de reassentamento, por exemplo, foi criado um marco regulatório. O Estado vem se esforçando para melhorar sua capacidade técnica e institucional para lidar com essas situações e com os investidores estrangeiros. Mosca e Selemane (2013) destacam que, não obstante o avanço com relação ao lançamento do marco regulatório pelo Estado, resta dúvida quanto à capacidade de o Estado fiscalizar a aplicação e o respeito a essa legislação, tendo em vista a carência de institucionalidade e de corpos técnicos qualificados no país, que possam garantir o cumprimento e a fiscalização da lei.

Atualmente, observa-se, no contexto moçambicano, a ampliação da atuação de outras empresas brasileiras. Estão presentes a Odebrecht, a OAS e a Andrade Gutierrez, que recebem financiamento do BNDES. ${ }^{14}$ Em Mo-

${ }^{13}$ Declarações de entrevistas e constatações da visita de campo em Cateme e 25 de setembro, em agosto de 2014.

${ }^{14}$ Com uma atuação bem inferior aos chineses com rela- 
çambique, estima-se que a carteira de projetos em análise, aprovados ou já contratados, chega a US\$ 800 milhões (Goes, 2014a). A Odebrecht entrou em Moçambique com a Vale, atuando nas instalações da mina de Moatize e, logo, na sua duplicação. Hoje, o principal projeto da empresa é a construção do aeroporto de Nacala, com um financiamento de US\$ 125 milhões do BNDES (Ibid.). Além do aeroporto, a Odebrecht está envolvida em um projeto de instalação de um BRT (Bus Rapid Transport) em Maputo (com crédito de US\$ 180 milhões do BNDES) e na implantação de uma zona franca industrial (US\$ 40 milhões do BNDES) (Odebrecht, s/d; Goes, 2014b). Já a Andrade Gutierrez está envolvida na construção da barragem Moamba Major, na bacia de Iconami, com um financiamento de US\$ 350 milhões do BNDES (Goes, 2014c). Por fim, a OAS atua no país junto aos projetos da Vale no que tange à parte da linha férrea no Corredor de Nacala e ao terminal portuário Nacala-a-Velha, para exportação exclusiva do carvão de Tete (Goes, 2014a). Não há informação precisa sobre financiamentos do banco à OAS.

$\mathrm{Na}$ área da cooperação internacional para o desenvolvimento, por sua vez, Moçambique é o principal receptor da cooperação brasileira prestada entre 2003 e 2010, totalizando $15 \%$ do total de valores executados (MRE, 2010). Na saúde, a principal instituição implementadora é a Fiocruz, que atua no forN talecimento institucional dos sistemas de saú- produção de medicamentos genéricos para o tratamento de HIV/AIDS e outras doenças é atualmente o segundo maior projeto na área de cooperação para o desenvolvimento. O total investido no projeto, que levou 10 anos entre negociação e funcionamento, foi de US\$ 23 milhões. O governo brasileiro doou R $\$ 13,6$ milhões e a Vale, por meio da Fundação Vale, doou US\$ 4,5 milhões para cobrir a parte que cabia ao governo moçambicano no empreendimento (Rossi, 2013).

No âmbito da agricultura, a cooperação brasileira legitima seu discurso nas semelhanças climáticas entre a savana moçambicana e o cerrado brasileiro (ver quadro em anexo). Sendo assim, a principal ideia por trás da cooperação na agricultura é aplicar, na realidade moçambicana, algumas "lições" que o Brasil aprendeu "em casa" ao desenvolver a sua agricultura, seja ela familiar ou empresarial. Duran e Chichava (2014, p. 402) identificam três grandes tendências da cooperação técnica brasileira na agricultura moçambicana: i) os programas desenvolvidos se valem do sucesso que tiveram na sua aplicação no Brasil; ii) existe uma oferta diversificada que envolve diferentes "propostas" para o desenvolvimento da agricultura moçambicana (alguns contraditórios ou conflituosos); iii) uma grande variedade de atores estão envolvidos, desde movimentos sociais até agências estatais. Um traço da cooperação brasileira tem sido a realização de iniciativas trilaterais, seja com potências do Norte (como EUA, Japão e outros) seja com organismos internacionais ou multilaterais como o PNUD e a FAO das Nações Unidas e outros (Fingermann, 2014).

O maior e mais visado projeto de cooperação brasileira em Moçambique, na área de agricultura, é o ProSavana. Idealizado pelos chefes de Estado do Brasil e do Japão e lançado, em 2009, de forma "silenciosa" 15 (Schle${ }^{15}$ O ProSavana foi idealizado em conversas bilaterais entre Brasil e Japão na Cúpula do G8 realizada em L'Aquila. Naquela ocasião, como relembra Ferrando (2013), o presidente Luís Inácio Lula da Silva e o primeiro ministro japonês Taro Aso concordaram em cooperar para o desenvolvimento agrícola da África, tendo Moçambique sido 
singer, 2013; Fingermann, 2014; Mosca, 2014), o projeto será desenvolvido em 19 municípios das províncias de Niassa, Zambézia e Nampula. Com inspiração no Prodecer, programa de cooperação entre Brasil e Japão desde a década de 1970 e que resultou no avanço no cerrado brasileiro da agricultura de larga escala para exportação, o ProSavana tem três vetores principais: o aumento da produtividade e a diversificação da agricultura; o estabelecimento de cadeias de valor agrícola; e a garantia do uso sustentável dos recursos naturais. Os beneficiários-alvo do programa seriam os agricultores de pequena e média escala, que progressivamente seriam integrados às cadeias do agronegócio (ProSavana, 2013, p. 18). A inserção se daria pela consolidação de clusters agrícolas e pela conversão da agricultura de subsistência (e com base no pousio) em comercial, com o fortalecimento de uma agricultura fixa e tecnificada (consumidora de insumos químicos, máquinas e equipamentos), integrada às cadeias agroexportadoras.

O andamento do programa, contudo, tem esbarrado em muitos problemas operacionais que vão desde o aumento das críticas e da resistência da sociedade civil organizada dos três países (devido à falta de transparência em suas ações e aos impactos que ele pode ter sobre a agricultura camponesa moçambicana), até atrasos e revisões de cronogramas por parte dos parceiros (em especial pela atuação da cooperação brasileira). Organizações da sociedade civil e movimentos sociais moçambicanos sintetizam assim o programa: o Brasil realiza a transferência de tecnologia e incentiva investimentos de grandes grupos do agronegócio, o Japão realiza a comercialização no mercado internacional e Moçambique cede as terras do corredor de Nacala (Monjane, 2015).

Diante das muitas críticas e polêmicas, recentemente foi notada uma tentativa de muescolhido e se juntado como parceiro posteriormente. A iniciativa se insere no contexto pós-crise internacional dos alimentos (2008), que acabou provocando uma "corrida" internacional (e, principalmente, entre países desenvolvidos) por terras com grande impacto sobre África e América Latina (Clements eFernandes, 2013). dança no discurso do programa. Assim,

[...] de um programa inicialmente concebido para ser executado por grandes empresas de agricultores estrangeiros, com tecnologias intensivas em capital, principalmente para a produção de soja e milho para exportação, passou-se para uma concepção de desenvolvimento através de pequenas e médias empresas, com envolvimento de agricultores moçambicanos e de pequenos produtores (Mosca, 2014).

O autor, contudo, aponta para o risco de que as mudanças no discurso não signifiquem mudanças reais, impedindo-o de se tornar um vetor promotor do desenvolvimento agrícola e rural em Moçambique. Atualmente, o ProSavana se encontram em um momento de reformulação e de tentativa de contornos das críticas e denúncias para a retomada de sua implementação. ${ }^{16}$

\section{INTERESSES EMPRESARIAIS E PO- LÍTICAS PÚBLICAS: convergências entre investimento e cooperação no Corredor de Nacala}

A política de cooperação triangular entre Brasil, Japão e Moçambique é idealizada e estruturada em estreita sintonia com os planos logísticos de atuação da Vale no norte de Moçambique. O ProSavana entende o desenvolvimento e a modernização do setor agropecuário moçambicano a partir do estabelecimento de corredores logísticos que ligam as áreas de extração mineral em grande escala, como a mineração de carvão na Província de Tete e a exploração de gás natural na Província de Cabo Delgado, aos portos exportadores para os mercados asiáticos. O estabelecimento e a recuperação do corredor logístico no norte do país é peça-chave para os investimentos naquela região e elemento ativador da reconfiguração do território, direcionando -o para a lógica de atuação das grandes cadeias agropecuárias e minerais.

${ }^{16}$ No primeiro semestre de 2015, foram realizadas, em todos os 19 distritos que envolvem o ProSavana, reuniões de auscultações relacionadas à versão zero do Plano Diretor do ProSavana. As reuniões foram envoltas em denúncias de falta de transparência e irregularidades por parte de organizações da sociedade civil e movimentos sociais (Monjane, 2015). 
A defesa da "vocação" e a consequente realização de investimentos na conformação de um corredor logístico no norte de Moçambique não são recentes. Historicamente, ainda na colonização portuguesa, o Corredor de Nacala foi um importante corredor internacional de transporte constituído pelo Porto de Nacala, o Caminho de Ferro do Norte e o sistema malauiano de ferrovia. Ross (2014) relembra que os "corredores de desenvolvimento" sempre constituíram um componente essencial da estratégia de desenvolvimento do pós-guerra em Moçambique. Em 1996, foi lançado o Programa de Iniciativas de Desenvolvimento Espacial (SDI), que deu início ao corredor de desenvolvimento de Maputo e que estabelecia oito ações do SDI. O Corredor de Nacala era um dos principais corredores de desenvolvimento. Em 2002, foi criada a Parceria para o Desenvolvimento da África (NEPAD) pela União Africana que, em 2007, adotou os corredores de desenvolvimento como instrumentos para planejar os investimentos empresariais no continente africano.

Nessa mesma perspectiva, o Banco Mundial realizou, em 2010, um estudo que tinha o objetivo de desenhar e implementar estratégias de desenvolvimento de polos de crescimento. A abordagem dos polos de crescimento procurou i identificar e selecionar sub-regiões dentro dos corredores para serem 焉 palco de projetos-piloto de desen@ volvimento econômico. A avaliação do Banco Mundial elencou as \& províncias de Tete e de Nampula a como projetos-piloto. Tete pelo 今ิ boom do setor da mineração. Na$\therefore$ cala pelas suas potencialidades na manufatura e logística. Também está prevista, nessa área, uma Zona Econômica Especial (ZEE), com um investimento de 1,2 bilhão de dólares em cerca de 53 projetos de agroprocessamento (Banco Mun- dial, 2010). O projeto do Banco Mundial, por sua vez, revela uma estreita sintonia com o ProSavana e as iniciativas de consolidação da infraestrutura do Corredor de Nacala.

$\mathrm{Na}$ mesma lógica e articulada com o projeto do Banco Mundial, a agência japonesa JICA elaborou o Projeto das Estratégias de Desenvolvimento Econômico do Corredor de Nacala (PEDEC), que atua sobre o corredor de Nacala e áreas adjacentes. Ela reconhece três forças motrizes para o desenvolvimento da região: a mineração de carvão e o transporte do carvão para exportação; a exploração de gás natural e a produção de GNL para exportação; e investimentos na Zona Especial Econômica de Nacala nas adjacências do Porto de Nacala (MPD e JICA, 2014).

Consequentemente, o desenvolvimento do corredor logístico tem atraído a atenção de diferentes atores, investidores e agências

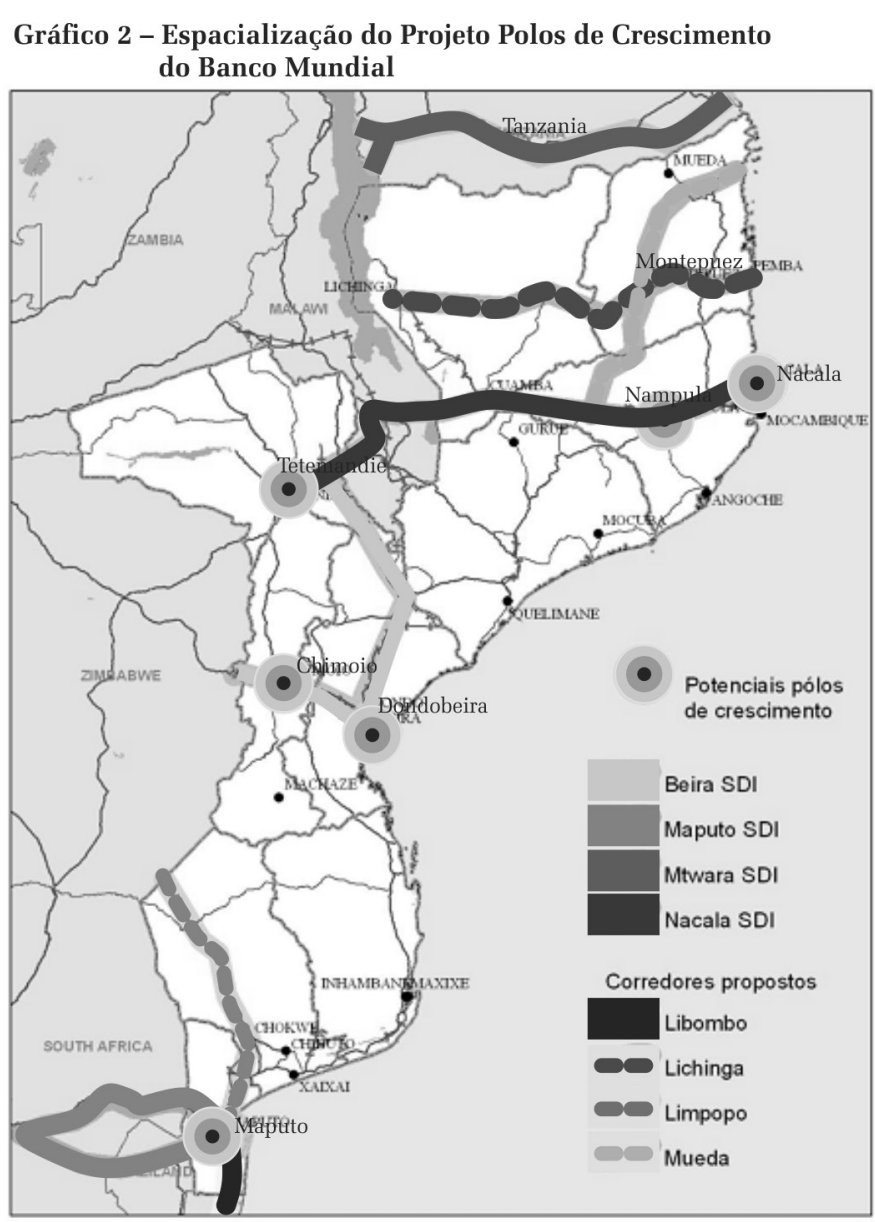

Fontes: Banco Mundial (2010). 


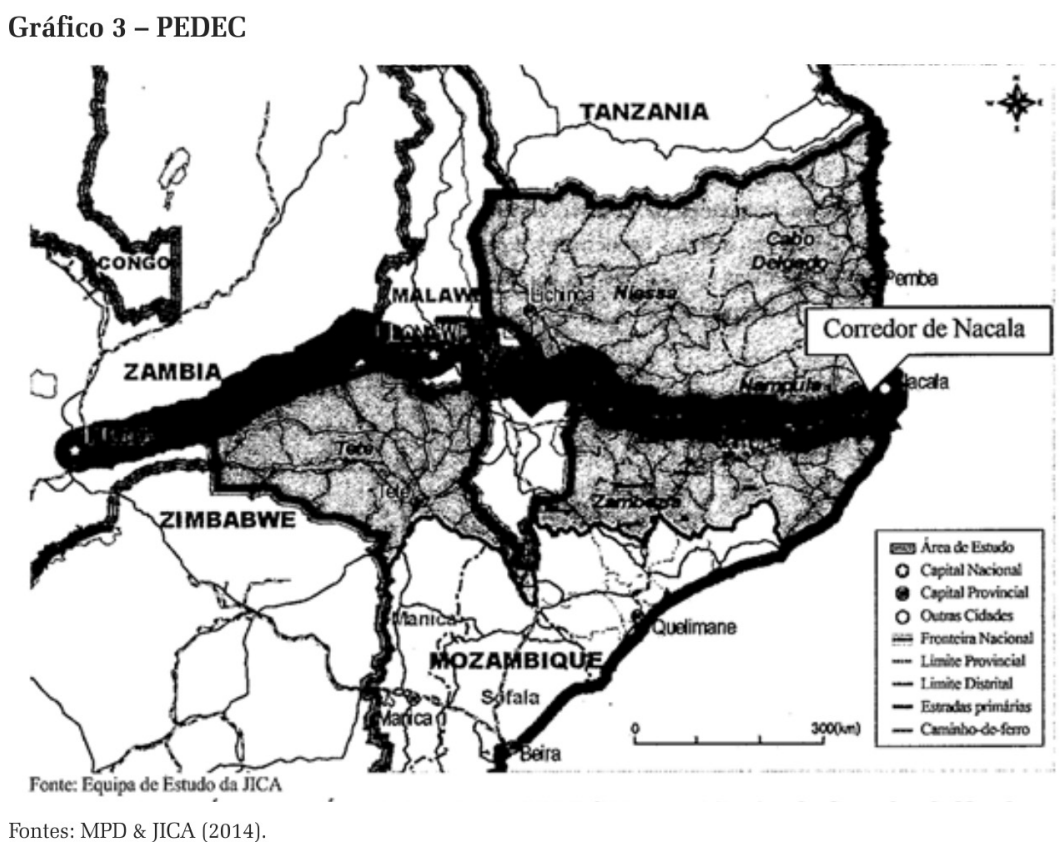

Fontes: MPD \& JICA (2014)

financiadoras (nacionais, internacionais e multilaterais), com interesses na ampliação da infraestrutura para escoamento do carvão e na expansão da fronteira agrícola no norte de Moçambique. Isso resultou na construção de novos fragmentos ferroviários entre Moatize e o Malauí e de interligação com Nacala-a-Velha, além da revitalização do Caminho de Ferro do Norte, incluindo Lichinga, Cuamba, Nampula e Porto de Nacala. O porto Nacala-a-Velha se tornou a "porta de saída do carvão de Moatize", com a construção de um terminal de uso exclusivo para a exportação de carvão (Vale e OAS). Os investimentos no corredor logístico estão articulados com a implementação da ZEE em Nacala (que visa ao fomento das atividades agroprocessadoras mediante a concessão de fartas isenções fiscais) e ao aeroporto de Nacala, construído pela Odebrecht com financiamento do BNDES (entrevistas realizadas em campo; Odebrecht, 2015; Coutinho, 2013).

A conversão de toda a infraestrutura e do tronco ferroviário para a finalidade de escoamento de commodities para os mercados internacionais tem se refletido em grandes impactos para a população local. De acordo com entrevistas realizadas em campo, a priorização do transporte de cargas sobre o transporte de passageiros tornou necessária a redução do tempo de viagens de um extremo ao outro (de 11 horas para 7 horas) e a ampliação dos trens de mercadorias em detrimento dos de passageiros. ${ }^{17}$ Ademais, foram fechadas várias estações (apeadeiros): de 27, apenas 7 se encontram hoje em funcionamento.

O fechamento dos apeadeiros causa grandes mudanças nas vidas das comunidades e maiores dificuldades nas alternativas de deslocamento. Na ausência de alternativas de transporte público, os trens eram a alternativa mais barata e mais utilizada pelos camponeses. As vinte comunidades que tinham apeadeiros, que hoje se encontram fechados, precisam se locomover até outras comunidades cujo apeadeiro ainda esteja funcionando, se quiserem utilizar o trem. Isso gera custos adicionais de deslocamento e, muitas vezes, de pernoite para garantir a chegada à estação a tempo de encontrar um lugar no trem. Ademais, tendo em vista a concentração de pessoas, os apeadeiros tendem a ser também importantes pontos de comercialização da produção agrícola local e de escoamento dos excedentes para o mercado de Nampula. Todas essas mudanças anunciam a nova lógica da infraestrutura e dos territórios, que passam a estar mais interligados às dinâmicas dos mercados internacionais e aos megaprojetos agropecuários e de exploração dos recursos minerais do que aos ritmos da vida e da produção das comunidades que margeiam a linha férrea e que moram no norte mo-

${ }^{17}$ Segundo entrevistas, após a mudança na concessão da ferrovia, as viagens de trem de passageiros foram cortadas pela metade. Essas informações foram obtidas em pesquisa de campo, por meio de entrevistas realizadas no apeadeiro de Cuamba e em Mutuali. 
Çambicano. ${ }^{18}$

O Corredor de Nacala constitui peça indispensável para a viabilização do principal projeto de cooperação brasileira na área da agricultura, o ProSavana, e para as estratégias da Vale. Isso torna o Corredor de Nacala, no nosso entendimento, área privilegiada para identificar e analisar a sinergia entre os investimentos e as iniciativas implementadas pelas empresas brasileiras, em particular do setor de mineração e agropecuário, e as políticas de cooperação. Os investimentos e a cooperação convergem para ampliar e favorecer a consolidação de cadeias globais de valores minerais e agropecuários, interligadas aos mercados internacionais. Moçambique se insere, assim, na órbita do capital transnacional (incluindo o brasileiro) como território para maior acumulação global.

Além disso, a presença brasileira em Moçambique - seja na cooperação, seja no investimento do setor privado - não está isolada da atuação das instituições financeiras internacionais, nem pode ser considerada mais "desinteressada" ou "solidária" se comparada à atuação de outras potências. Num quadro maior de acumulação capitalista, ela responde a uma lógica de disputa por recursos naturais e acesso a mercados, em uma competição de cunho imperialista, cujo palco se desloca, nos Ð tempos atuais, de volta para a África.

\section{CONCLUSÕES} \& brasileira e os investimentos privados em Moiิ çambique. Para compreender melhor o papel

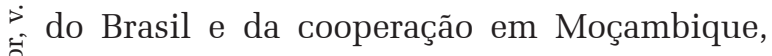
precisamos sair do plano generalista e avançar no entendimento da dinâmica real que está

${ }^{18}$ Durante a pesquisa de campo, em agosto de 2014, em visitas a duas comunidades, pudemos perceber as mudanças ocasionadas no território pela conversão da ferrovia para a lógica de transporte de mercadorias (no lugar de passageiros). Essas comunidades foram Mutuali e Cuamba. por trás e que sustenta a chegada das empresas privadas (seja de mineração ou de agricultura empresarial) aos territórios. O caso aqui estudado demonstra que a principal iniciativa de cooperação brasileira se dá em territórios sobrepostos àqueles mirados pelos interesses dos principais grupos econômicos brasileiros, como a Vale e as empreiteiras, assim como pela cooperação Norte-Sul (como pela agência japonesa JICA), e por algumas das principais instituições financeiras multilaterais, como Banco Mundial. Isso nos leva a demarcar, ao menos de forma inicial, a convergência de atores e iniciativas na cadeia produtiva de commodities minerais e agrícolas, parte essencial da acumulação global capitalista, na qual o Brasil se insere como um dos atores da cadeia. Dessa forma, a cooperação e os investimentos entre países do Sul configuram não tanto uma alternativa, mas sim uma parte integral das relações de poder no plano internacional.

Juntamente com as empresas, sobressai o papel desempenhado pelo Estado moçambicano na organização e facilitação do avanço do capital, garantindo concessões de uso da terra, bem como fazendo mediação com as famílias camponesas expropriadas de suas terras ou que ficaram desatendidas pelo transporte ferroviário, agora com lógica convertida para o transporte de mercadorias. Nas comunidades visitadas, os entrevistados entendiam que as negociações de indenizações e remoções eram tocadas pelo Estado moçambicano, ainda que todos os documentos indicassem a autoria da CDN, Corredor de Desenvolvimento do Norte, controlada pela Vale. O mesmo se deu nas comunicações sobre mudanças nos horários dos trens de passageiros. Não foi à toa que, ao atuar no Corredor Logístico, a Vale optou por estabelecer sociedades com o governo moçambicano. Com relação ao Estado brasileiro, ao longo de todo o Corredor Logístico, sobressai o financiamento público do BNDES para as construtoras brasileiras, na ampliação da mina de Moatize e na construção do aeroporto de Nacala, bem como a política de cooperação em 
agricultura. Apesar do discurso da horizontalidade e o reconhecimento da dívida histórica da sociedade brasileira para com a África, o aprofundamento das relações se dá num cenário internacional que vislumbra novas formas de inserção das economias africanas e da brasileira na ordem mundial. O Brasil procurou, ao longo dos últimos anos, ganhar destaque e importância em espaços de negociação e diálogo multilaterais. Boa parte dos países África lusófona, por sua vez, impulsionada pelo boom das commodities e sustentada por mudanças nos seus sistemas políticos - com a adoção de políticas de liberalização comercial e de incentivo aos investimentos estrangeiros - passou a ser foco de muitos investimentos internacionais, tendo como contrapartida um processo crescente de "estrangeirização" da terra. Nesse cenário, a África lusófona tem se tornado um campo de férteis oportunidades para o Brasil, tanto no plano econômico como no político. A complexa teia estabelecida entre as pernas do tripé investigadas nesta pesquisa parece refletir isso.

No processo de desenvolvimento mundial desigual, o Brasil se encontra diante de profundo dilema entre ser "explorador" e ser "explorado", num interior cinzento que não é centro nem periferia. Ao mesmo tempo em que sua atuação, em alguns momentos, parece buscar o rompimento com determinados "papéis" que lhe estariam reservados no cenário internacional, incluindo-se num movimento maior de promotor de uma "nova ordem mundial”, com maior protagonismo dos países do Sul, noutros se alinha e age de maneira a reafirmar seu lugar na corrida imperialista das principais potências mundiais, reservando sua posição de potência regional que se ancora, sobretudo, nas relações de exploração e poder mantidas com as suas periferias. Se, historicamente, o Brasil reivindicou sua soberania sobre os recursos naturais e energéticos (com a nacionalização da Vale e da Petrobras na década de 1950, no período Vargas, por exemplo), hoje avançamos, com essas mesmas empresas, na exploração de bens e recursos naturais de outros países e regiões. Isso vem se materializando, também, na ocupação do território africano pelo capital brasileiro. Esse avanço também pode ser observado no campo das ideias, com o crescimento das transferências de políticas públicas brasileiras e seus conceitos para o contexto africano.

Não obstante o sentimento pessimista que o caso estudado parece sugerir, ele nos lembra também que a realidade é dinâmica e está aberta a novas e a outras possibilidades. A rápida articulação entre interesses privados e públicos em torno da política de cooperação também se fez acompanhada de uma maior interação e parceria, de caráter transnacional, entre diferentes atores da sociedade civil, movimentos sociais e outros. As lutas contra as violações de direitos humanos, trabalhistas e ambientais causados pela atuação da Vale no mundo já se encontra articulada internacionalmente. ${ }^{19}$ Se, ao entrar em Moçambique, empresas multinacionais como a Vale, atuando junto com o Estado moçambicano, parecem grandes atores imponentes, hoje já precisam se respaldar em políticas de responsabilidade social e atuar no marco regulatório para reassentamentos, diante de uma opinião pública nacional e internacional bastante atenta. Por sua vez, o ProSavana, que parecia ser uma profecia inescapável, tendo em vista a aliança de interesses que corporificava, não vem conseguindo avançar em seu cronograma. Passados dois anos, somente agora são realizadas as auscultações sobre o Plano Diretor. O projeto original não pode ser implementado como estava previsto, devido à formação de uma ampliada luta de resistência e de denúncia. Não obstante as fragilidades e fragmentações que esse leque variado de atores implica, no momento atual de desenvolvimento das ferramentas e tecnologias de comunicação, as articulações internacionais (como os "Atingidos pela Vale", ou a rede trinacional da campanha "Não ao ProSa${ }^{19}$ Articulação Internacional dos Atingidos pela Vale: https://atingidospelavale.wordpress.com/ 
vana” ${ }^{20}$ ) acabam se tornando um importante empecilho para a violação dos direitos das comunidades camponesas e trabalhadoras.

No futuro próximo, a luta de resistência e a dinâmica do norte de Moçambique sofrerão importantes mudanças ativadas com o início de funcionamento do corredor logístico de Nacala. Se, por um lado, a consolidação da infraestrutura pode ser um importante fator impulsionador do agronegócio pelo efeito de antecipação e pela mudança no controle do território, por outro, a concretização da cadeia de valor da mineração no território pode contribuir para a criação de uma unidade das diversas resistências ao projeto. A trajetória percorrida até aqui nos sugere que, enquanto o impasse se arrasta, oportunidades reais de aproximação da política de cooperação brasileira dos valores que são reivindicados pelo governo brasileiro no seu discurso parecem ser desperdiçadas e pouco valorizadas.

Recebido para publicação em 11 de setembro de 2015 Aceito em 20 de dezembro de 2015

\section{REFERÊNCIAS}

AMORIM, C. A África tem sede de Brasil. Carta Capital, 28 de maio de 2011.

BANCO CENTRAL DO BRASIL (BCB). Capitais brasileiros - no exterior (CBE). Ano-base 2013. Disponível em http:// ㄱำ www4.bcb.gov.br/rex/CBE/Port/ResultadoCBE2013p.pdf. Acesso em 01/11/2015.

迆

BANCO MUNDIAL. Perspectivas para os Polos de Crescimento em Moçambique: sumário do relatório. ‡ Agosto de 2010. Disponível em http://www.iese.ac.mz/ @ lib/publication/outras/cd_ppi/pastas/governacao/geral/ ó legislativo_documentos_oficiais/Polos_Desenv.pdf. S) Acesso em $\overline{01} / 11 / 2015$.

i.

BNDES. BNDES inaugura escritório de representação na

$\stackrel{0}{\wedge}$ África, 06/12/2013. Disponível em http://www.bndes.

д gov.br/SiteBNDES/bndes/bndes_pt/Institucional/Sala

de_Imprensa/Noticias/2013/Todas/20131206_africa.html. จ Acesso em 01/11/2015.

i. Planilhas com as operações de exportação oิ pós-embarque. Disponível em: http://www.bndes.gov. శ. br/SiteBNDES/bndes/bndes pt/Institucional/BNDES

글 Transparente/consulta_as_operacoes_exportacao/planilhas œ exportacao_pos_embarquē.html. Acesso em 01/11/2015.

${ }^{20} \mathrm{O}$ lançamento da campanha se deu em um encontro entre organizações e movimentos sociais do Brasil, Moçambique e Japão, em Maputo, em 2012. Ver: http://www.unac. 新 org.mz/index.php/artigos/nacional/94-campanha-nao-ao J -prosavana-mocambicanos-pedem-solidariedade-regional
CASTRO, C. M. de. Brazil's Cooperation with Sub-Saharan Africa in the Rural Sector. Latin American Perspectives, issue 198, v. 41, n. 5. set. de 2014.

CERVO, A. A internacionalização da economia brasileira. Livro na Rua, Série Diplomacia ao alcance de todos, n. 20. Brasília: FUNAG/Thesaurus Editora, 2009.

CLEMENTS, E. A.; FERNANDES, B. M. Estrangeirização da terra, agronegócio e campesinato no Brasil e Moçambique. Maputo: Observatório do Meio Rural, 2013.

CAMPOS, P. H. Estranhas Cadetrais. As empreiteiras brasileiras e a ditadura civil-militar 1964-1988. Niterói: Editora da UFF, 2014.

COUTINHO, L. Investimento, financiamento e o BNDES. Apresentação de Power Point. Disponível em: http://www. bndes.gov.br/SiteBNDES/export/sites/default/bndes_pt/ Institucional/Sala_de_Imprensa/Galeria_Arquivos/CĀE FINAL.pdf. Acessōem 01/07/ 2015.

COX, R. W. Power, production and world orders. Social forces in the making of history. Colombia University Press, New York, 1987.

DURAN, J.; CHICHAVA, S. O Brasil na agricultura moçambicana: parceiro de desenvolvimento ou usurpador de terra? Desafios para Moçambique 2013. Disponível em: http:/www.iese.ac.mz/lib/publication/livros/des2013/ IESE_Des2013_15.BrasAgrMoc.pdf. Acesso em 01/10/2014.

DURÃO, M.; CIARELLI, M. Vale vende à japonesa Mitsui fatia de ativos de carvão em Moçambique. Estado de São Paulo, 10/12/ 2014

ESTADO DE SÃO PAULO. Ordem na Vale é "desinvestir". 10/12/2014.

FERRANDO, T. Dr. Brasilia and Mr. Nacala: The apparent duality behind the brazilian state-capital Nexus (July 2, 2013). Disponível em: http://ssrn.com/abstract $=2288940$. Acesso em 01/07/ 2015.

FINGERMANN, N. N. A cooperação trilateral brasileira em Moçambique: um estudo comparado do ProALIMENTOS e o ProSAVANA. 2014. (Tese), Fundação Getúlio Vargas, São Paulo.

FUNDACAO DOM CABRAL (FDC). Ranking FDC das multinacionais brasileiras 2014. A força da marca Brasil na criação de valor internacional. Disponível em http:// www.fďc.org.br/blogespacodialogo/Documents/ranking fdc multinacionais brasileiras2014.pdf. Acesso em $01 / \overline{1} 1 / 2015$.

GARCIA, A.; KATO, K.; FONTES, C. A história contada pela caça ou pelo caçador? Perspectivas do Brasil em Angola e Moçambique. Rio de Janeiro: PACS, 2013.

Multinacionais brasileiras durante o governo Lula. Uma análise crítica sobre a relação entre capital e Estado no Brasil contemporâneo. Rio de Janeiro: Novas Edições Acadêmicas, 2015.

GIUGALE, M. Who will be Africa's Brazil? Disponível em http://www.huffingtonpost.com/marcelo-giugale/who-willbe-africas-brazi b 1370652.html?view=print\&comm ref $=$ false. Acesso e⿳亠丷厂 01/11/2015.

GOES, F. Empreiteiras competem com as chinesas na África. Valor Econômico, 23/6/2014a

Odebrecht tem projeto de zona franca industrial. Valor Econômico, 23/6/2014b.

Andrade Gutierrez vai fazer barragem para Maputo. Valor Econômico, 23/6/2014

HARVEY, D. In what ways is the 'new imperialism' really new? Historical Materialism, n. 15, p. 57-70, 2007.

HARVEY, D. O "Novo Imperialismo": ajustes espaçotemporais e acumulação por desapossamento. Lutas Sociais, São Paulo: Neils, n. 13/14. 2005. 
IGLESIAS, R.; MOTTA VEIGA, P. Promoção de exportações via internacionalização de firmas com capital brasileiro, 2002. Disponível em http://www.bndes.gov.br/SiteBNDES/ export/sites/default/bndes pt/Galerias/Arquivos/ conhecimento/livro desafio/Relatorio-09.pdf. Acesso em $01 / 11 / 2015$

INSTITUTO ROSA LUXEMBURG STIFTUNG et. al. Empresas transnacionais brasileiras na América Latina. Um debate necessário. São Paulo: Editora Expressão Popular, 2009.

IPEA; ABC. Cooperação brasileira para o desenvolvimento internacional: 2005-2009. Brasília: Instituto de Pesquisa Econômica Aplicada; Agência Brasileira Cooperação, 2010

IPEA; BANCO MUNDIAL. Pontes sobre o Atlântico: Brasil e África Subsaariana parceria Sul-Sul para o crescimento, 2011. Disponível em: http://www.ipea. gov.br/portal/images/stories/PDFs/livros/livros/111222 livropontesobreoatlanticopor2.pdf. Acesso em 01/11/2015.

LAZZARINI, S. Capitalismo de laços: os donos do Brasil e suas conexões. Rio de Janeiro: Elsevier, 2011.

MACEDO, D. Mais alimentos para África promete abrir mercados para indústria nacional de máquinas agrícolas. Agência Brasil, 24/1/2011

MINISTERIO DE RELAÇÕES EXTERIORES (MRE). Balanço da Política Externa 2003-2010. Disponível em http://www.itamaraty.gov.br

Acordo Brasil-Moçambique de cooperação e facilitação de investimento (ACFI). Maputo, 30 de março de 2015. Disponível em: http://www.itamaraty.gov.br/index. php?option $=$ com content\&view $=$ article\&id $=8511 \&$ catid 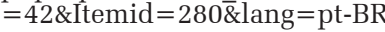

MILANI, C.; PINHEIRO, L. Política externa brasileira: os desafios da caracterização como política pública. Contexto Internacional, Rio de Janeiro, v. 35, n` 1, jan./jun, p. 11-41, 2013.

MILANI, C. R. S. CARVALHO, T. C. O. Cooperação Sul-Sul e política externa: Brasil e China no continente africano. Estudos Internacionais, Rio de Janeiro, v. 1. p. 1-7, 2013.

MPD \& JICA. O projeto das estratégias de desenvolvimento econômico do Corredor de Nacala na República de Moçambique (PEDEC-NACALA). v. 1 e 2. Jul. 2014. Disponível em: http://farmlandgrab.org/uploads/ attachment/Corredor_de_nacala_vol1.1.pdf. Acesso em $01 / 07 / 2015$.

MONJANE, B. Auscultação pública sobre ProSavana: ministro exige intervenções patrióticas e ativistas abandonam a sala. Disponível em https://adecru. wordpress.com/2015/06/15/auscultacao-publica-sobreo-prosavana-ministro-exige-intervencoes-patrioticas-eactivistas-abandonam-a-sala/. Acesso em 15/06/2015.

MOSCA, J. Porque é que a produção alimentar não é prioritária? Maputo: Observador Rural. n. 1, 2012 (documento de trabalho).

MOSCA, J. ProSavana. Maputo: Observatório do Meio Rural, Destaque Rural, n. 5. 2014.

MOSCA, J.; SELEMANE, T. Grandes projetos e segurança alimentar em Moçambique. Maputo março, 2013.

ODEBRECHT. Aeroporto Internacional de Nacala é inaugurado em Moçambique. 14/03/2015.

O PAÍS. Vale quer investir 6,4 bilhões USD na expansão da mina de Moatize. Disponível em: http://opais.sapo.mz/index.php/ economia/38-economia/21021-vale-quer-investir-64-bilioes-usdna-expansao-da-mina-de-moatize.html. Acesso em 01/11/2015.

PROSAVANA. Reuniões Distritais de Auscultação sobre a Versão Zero (Draft Zero) do ProSavana. 07/05/2015.

SANTOS, N. F. Moçambique obriga a participação estatal na exploração de petróleo e minas. Público. 18/08/ 2014.

SARAIVA, J. F. S. África parceiro do Brasil Atlântico: relações internacionais do Brasil e da África no início do século XXI. Belo Horizonte: Editora Fino Traço, 2012.

SCHLESINGER, S. Cooperação e investimentos do Brasil na África: o caso do ProSavana em Moçambique. Rio de Janeiro: FASE, 2013

SENNES, R.; MENDES, R. Políticas públicas e multinacionais brasileiras. In: ALMDEIDA; RAMSEY (orgs.). A ascensão das multinacionais brasileiras. O grande salto de pesos-pesados regionais a verdadeiras multinacionais. Rio de Janeiro: Elsevier; Belo Horizonte: Fundação Dom Cabral, 2009.

RECEITA FEDERAL BRASILEIRA. Acordos para evitar a dupla tributação. Disponível em http://www.receita. fazenda.gov.br/Legislacao/AcordosInternacionais/ AcordosDuplaTrib.htm. Acesso em 01/11/2015.

RENZIO, P. de; GOMES, G. Z.; FONSECA; J. M. E. M. da; NIV, A. O Brasil e a Cooperaçẫo Sul-Sul: como responder aos desafios correntes. Rio de Janeiro: Brics Policy Center, 2013.

ROSS, D. Moçambique em Ascensão. Construir um novo dia. Fundo Monetário Internacional, Washington, 2014

ROSSI, A. Projetos do Brasil ajudam países africanos, mas enfrentam dificuldades. Estado de São Paulo, 30/10/2013.

Governo Dilma implementa “agenda África” para ampliar relações. Estado de São Paulo, Brasil, 29/10/2013.

UNAC; GRAIN. Os usurpadores de terras do Corredor de Nacala: uma nova era de luta contra plantações coloniais no Norte de Moçambique. Maputo: Grain e UNAC, 2015 (relatório).

UNCTAD. Informe sobre las inversiones en el mundo 2006. La inversión extranjera directa de los paises en desarrollo y economias en transición: consecuencias para el desarrollo. Disponível em http://www.unctad.org/en/ docs/wir2006_en.pdf. Acesso em 01/11/2015.

Informe sobre as inversiones en el mundo 2014. Invertiren los objetivos del desarollo sostenible: plan de acción. Disponível em http://unctad.org/es/ PublicationsLibrary/wir2014 overview es.pdf. Acesso em $01 / 11 / 2015$

VALE. Além da mineração: promovendo desenvolvimento sustentável através da mineração responsável. Apresentação de PowerPoint, 2013. Disponível em: http:// www.valor.com.br/sites/default/files/rafael benke.pdf. Acesso em 01/07/2015.

Investimento da Vale em Logística nos Últimos 6 anos é de US\$ 9 bi. Especial Logística, fevereiro, 2011.

Relatório de Sustentabilidade 2014. Disponível em http:/www.vale.com/PT/aboutvale/sustainability/ links/LinksDownloadsDocuments/relatorio-desustentabilidade-2014.pdf. Acesso em 01/11/2015.

Sustentabilidade Moçambique 2013. Disponível em http://www.vale.com/mozambique/pt/documents/ vale sustentabilidade mocambique 2013.pdf. Acesso em $01 / 1 \overline{1} / 2015$.

VALOR ECONOMICO. Revista Multinacionais Brasileiras, outubro 2009

VIGENANI; CEPALUNI. A política externa de Lula da Silva: a estratégia da autonomia pela diversificação. Contexto Internacional, Rio de Janeiro, v.. 29, n. 2, jun-jul 2007. 
PUBLIC POLICIES AND PRIVATE INTERESTS: an analysis from the Nacala corridor in Mozambique

\author{
Ana Garcia \\ Karina Kato
}

From 2003, Brazilian external politics presented a noticeable curve towards deepening and expanding relations with other countries from the "Global South". In this context, the African continent gained importance for Brazilian international relations. The goal of this article is to advance the understanding of the participation of the business sector for the Brazilian cooperation in Mozambique. The results showed that companies and their private projects were mixed in the territories. We examined the case of the Nacala corridor, an intersection of the main and largest cooperation and investment initiatives from Brazilian companies in Mozambique. The resulting scenario shows a game board in which the South-South cooperation and, inside it, Brazilian cooperation, cannot be understood without considering their relations with business interests and investments, the power struggles with other countries and the policies from multi-lateral institutions like the World Bank.

KeYwords: Brazilian multinationals. Infrastructure. South-South Cooperation. Mozambique. Development.

\section{Ana Garcia \\ Karina Kato}

La politique étrangère brésilienne, à partir de 2003, a montré un virage marqué par l'approfondissement et l'élargissement des relations avec d'autres pays et régions du Sud. Dans ce contexte, l'Afrique a pris de l'importance pour les relations internationales du Brésil. L'objectif de cet article est de mieux comprendre la participation du secteur privé dans la coopération brésilienne au Mozambique. Les résultats montrent que les entreprises et leurs projets privés sont mélangés dans les territoires. Nous examinons le cas du couloir logistique de Nacala, qui montre l'intersection des principales initiatives de coopération et d'investissement des entreprises brésiliennes au Mozambique. Le scénario construit montre un tableau dans lequel la coopération Sud-Sud - et la coopération brésilienne-, ne peut être comprise sans tenir compte sa relation avec les intérêts et les investissements des entreprises, les relations de pouvoir avec d'autres pays et les politiques d'institutions multilatérales comme la Banque Mondiale.

Mots CLÉs: Multinationales brésiliennes. Infrastructures. Coopération Sud-Sud. Mozambique. Développement.

Ana Garcia - Doutora em Relações Internacionais pelo IRI/ PUC-Rio e mestre em Ciência Política pela Universidade Livre de Berlim. Professora do Departamento de História e Relações Internacionais na Universidade Federal Rural do Rio de Janeiro (UFRRJ). Coordenadora do Laboratório Interdisciplinar de Estudos de Relações Internacionais (LIERI/UFRRJ). Pesquisadora colaboradora do Instituto Políticas Alternativas para o Cone Sul (PACS). Tem experiência na área de Economia Política Internacional, atuando nos seguintes temas: Teoria Critica, Gramsci, hegemonia, imperiaslismo, empresas transnacionais e relações Sul-Sul. Publicações recentes: BRICS, an anti-capitalist critique (co-edited with Patrick Bond), Jacana, South Africa, 2015; Desenvolvimento desigual na era do conhecimento: a participação dos BRICS na produção científica e tecnológica mundial. Contexto Internacional (on-line), v. 37, p. 215-253, 2015; A história contada pela caça ou pelo caçador? Reflexões sobre a inserção do Brasil na África. Tensões Mundiais (Impresso), v. 10, p. 145-172, 2014.

Karina Kato - Doutora em Desenvolvimento, Agricultura e Sociedade (CPDA). Professora do Programa de Pós-Graduação de Ciências Sociais em Desenvolvimento, Agricultura e Sociedade, do Departamento de Desenvolvimento, Agricultura e Sociedade (DDAS), do Instituto de Ciências Humanas e Sociais (ICHS), da Universidade Federal Rural do Rio de Janeiro (UFRRJ). Pesquisadora do Observatório de Políticas Públicas para a Agricultura (OPPA) e do Grupo de Estudos sobre Mudanças Sociais, Agronegócio e Políticas Públicas, ambos vinculados ao CPDA/UFRRJ. Pesquisadora colaboradora do Instituto Políticas Alternativas para o Cone Sul (PACS) e vice-coordenadora do Laboratório Interdisciplinar de Estudos em Relações Internacionais (LIERI/UFRRJ). Publicações recentes: O rural contemporâneo nas políticas públicas brasileiras trabalho pela internet. Cronos (Natal. Impresso), v. 14, p. 04-22, 2013; The biodiesel market and public policy: a comparative analysis of Argentina and Brasil. CEPAL Review (Print), v. 1, p. 69-86, 2012; Dilemas institucionais na promoção dos biocombustíveis: o caso do programa nacional de produção e uso de biodiesel no Brasil. Cadernos do Desenvolvimento, v. 8, p. 329-354, 2011. 